\title{
Anthocyanin Extraction from Clidemia hirta (L.) D. Don Fruit and Its Stability During Storage
}

\author{
Gayatri Annisa Larasati ${ }^{1}$, Irvan Setiadi Kartawiria ${ }^{2}$ Abdullah Muzi Marpaung ${ }^{1 *}$ \\ ${ }^{1}$ Food Technology Department, Swiss German University, Tangerang, Indonesia \\ ${ }^{2}$ Chemical Engineering Department, Swiss German University, Tangerang, Indonesia \\ *Corresponding author.Email: abdullah.muzi@sgu.ac.id
}

\begin{abstract}
There have been concerns regarding the use of artificial food colorant, triggering the food industry to develop natural food colorant with nutraceutical properties, which could be solved by anthocyanins. A series of studies to evaluate the potency of harendong bulu (Clidemia hirta (L.) D. Don) fruit as the source of anthocyanin was conducted. First, the selection of time $\left(30,60\right.$, and 90 minutes) and temperature $\left(30^{\circ} \mathrm{C}, 45^{\circ} \mathrm{C}\right.$, and $\left.60^{\circ} \mathrm{C}\right)$ of aqueous extraction at $\mathrm{pH} 1$. Second, the evaluation of anthocyanin characteristics and stability of the extract at $\mathrm{pH} 1,3,5,7$, and 9 . Extraction at $60^{\circ} \mathrm{C}$ for 30 minutes gave the best result with $43.81 \pm 2.99 \mathrm{mg} / \mathrm{L}$ total monomeric anthocyanin and $1.31 \pm 0.12 \mathrm{~g} / \mathrm{L}$ phenolic compound as gallic acid equivalent. $C$. hirta expresses red color at $\mathrm{pH} 1$ and 3 . At $\mathrm{pH} 5$, it showed a unique characteristic by expressing deep blue color at $\mathrm{pH}$. However, the high browning index and low color stability at the $\mathrm{pH}$ have not supported the extract as the potential food colorant. The extract exhibited the best anthocyanin quality and stability at $\mathrm{pH} 1$ by showing bright red color, low browning index, and high color stability ( $\mathrm{t} 0.5=126.85 \mathrm{~d}$ ). The best performance of $\mathrm{C}$. hirta at the range of food $\mathrm{pH}$ was at $\mathrm{pH} 3$. At the $\mathrm{pH}$, even though the $50 \%$ monomeric anthocyanin disappeared in 5.7 days, C. hirta retained its $50 \%$ color for 21 days at room temperature. Hence, C. hirta showed its promising performance as the red colorant for high acidic food products.
\end{abstract}

Keywords: anthocyanin, Clidemia hirta, colorant, stability.

\section{INTRODUCTION}

There are two potential benefits of anthocyanins in a food product, first as a coloring agent and second as a functional ingredient. Anthocyanins provide a broad spectrum of colors, such as red, orange, purple and blue. However, most anthocyanins are colorless or easily decolorized at the range of $\mathrm{pH}$ of food. Only the exclusive anthocyanins, called poly acylated anthocyanins, show relative high color intensity and stability at the low acidic and neutral conditions [1,2]. Despite losing its color, anthocyanin remains the health beneficial effect, as an antioxidant, antidiabetic, anti-cancer, antihypertensive, etc [3].

Clidemia hirta (L.) D. Don, commonly called soapbush or harendong bulu in Indonesia, is an invasive perennial shrub that is widely found in tropical regions [4]. It has small clustered fruits that have purplish-blue color when ripe (Figure 1), and the taste is sweet. Local people in West Java, Indonesia, commonly eat the berries while walking in the woods. The old and the only study reported that the berry contains acylated delphinidin 3,5O-diglucoside [5]. There is no specific report to identify the number of acyl groups in the anthocyanins of $C$. hirta.

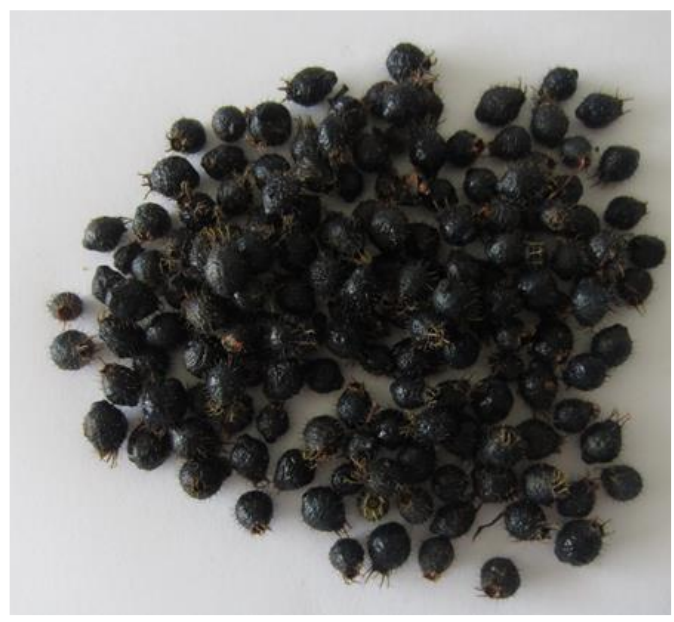

Figure 1 Clidemia hirta berries. 
Nevertheless, a study showed that the extract of $C$. hirta almost colorless at $\mathrm{pH} 4$ [6]. This behaviour is an appropriate indicator that the anthocyanin is not polyacylated but monoacylated anthocyanin. Hence, the $C$. hirta berry is not a potential coloring agent for food at $\mathrm{pH} 4$. However, several reports showed that plant extract containing simple anthocyanin performed a relatively high color intensity and stability at $\mathrm{pH} 3$.

With this background, we are interested in studying the color quality of anthocyanin in $\mathrm{C}$. hirta berry extracts and its stability at various $\mathrm{pH}$. This research aimed to evaluate how potent the $\mathrm{C}$. hirta extract is as the source of food colorant, especially at $\mathrm{pH} 3$ [7].

\section{MATERIALS AND METHOD}

\subsection{Materials}

The $C$. hirta berries obtained from the plant wildly grown in National Park Halimun-Salak Mountain Bogor, West Java, Indonesia. The fresh berries were collected, steam-blanched for 6 minutes [7], hot air dried at $40^{\circ} \mathrm{C} 24$ hours, powdered and sieved through a $250 \mu \mathrm{m}$ screen. The powder was stored in a tight dark glass bottle and kept in a freezer $\left(-20^{\circ} \mathrm{C}\right)$ until used. The deionized water obtained from the local market (Amidis ${ }^{\circledR}$ ) and the 2,2diphenyl-2-picrylhydrazyl from Sigma Aldrich, Germany. Buffer solution $\mathrm{pH}$ 3, 5, 7, 9. Hydrochloric acid, potassium chloride, sodium carbonate, citric acid, sodium citrate, aluminium chloride, sodium metabisulfite, methanol, potassium acetate, FolinCiocalteu reagent, and gallic acid procured from Merck® (Darmstadt, Germany). The reagents were analytical grade.

\subsection{Selecting the time and temperature of extraction}

The aqueous extraction was conducted using $40 \mathrm{ml}$ of $0.1 \mathrm{~N} \mathrm{HCl}$ per one gram of berry powder in the dark with continuous shaking. The three different levels of temperature and time were applied $\left(30,45,60^{\circ} \mathrm{C}\right.$ and 30 , 60 , 90 minutes, respectively). The filtrate of the suspension collected and centrifuged at $7000 \mathrm{rpm}$ for 5 minutes. The best extraction parameter was chosen based on the total monomeric anthocyanin and total phenolic yielded.

\subsection{Anthocyanin quality and stability of the best extract at various $\mathrm{pH}$}

The best extraction parameter was chosen based on the total monomeric anthocyanin and total phenolic yielded. The best extraction parameter used to produce $C$. hirta extract that underwent the anthocyanin quality and stability test at $\mathrm{pH} 1,3,5,7,9$. The quality and stability observed were total monomeric anthocyanins, color intensity, violet index, and browning index.

All samples are bottled in dark vials and stored in a dark container at room temperature. The color intensity and total monomeric anthocyanin observed periodically depend on the $\mathrm{pH}$.

The most stable extract was characterized by the total phenolic content, flavonoid content, and antioxidant activity.

\subsection{Total monomeric anthocyanin analysis}

The monomeric anthocyanins (TMA) content is measured as delphinidin 3-glucoside by the $\mathrm{pH}$ difference method [7]. The method was based on the characteristic of monomeric anthocyanins, which solely exist as red flavylium cation (AH+) at $\mathrm{pH} 1$ and converted to colorless carbinol pseudobase (B) at $\mathrm{pH}$ 4.5. The difference of absorbance at peak wavelength will be proportional to monomeric anthocyanins content.

The analysis was done by placing $0.9 \mathrm{ml}$ of buffer solution $\mathrm{pH} 1$ (potassium chloride - hydrochloric acid) and $\mathrm{pH} 4.5$ (citric acid - sodium citrate) buffer in a test tube and then added with $0.1 \mathrm{ml}$ of the sample. The blank solution is prepared by replacing $0.1 \mathrm{ml}$ of sample with $0.1 \mathrm{ml}$ of distilled water. The $\mathrm{pH} 1$ sample was first scanned by a UV-VIS Spectrophotometer (Genesys 10uv Thermo Electron Corporation, USA) to identify the peak. Then, all samples were measured for absorbance at the peak wavelength and at $700 \mathrm{~nm}$. The absorbance obtained was then used to calculate the monomeric anthocyanins content with the following equations.

$\left.A=\left(A \lambda_{\max }-A 700\right)_{p H 1}\right)=\left(A \lambda_{\max }-A 700\right)_{p H 4.5}$.

$\operatorname{TMA}(\mathrm{mg} / \mathrm{L})=(\mathrm{A} \times \mathrm{MW} \times \mathrm{DF} \times 1000) /(\varepsilon \times \mathrm{l})$

A is the absorbance, MW is molecular weight of delphinidin 3-glucoside (465.2 g. $\mathrm{mol}^{-1}$ ), DF is a dilution factor, $\varepsilon$ is molar absorptivity $\left(29,000 \mathrm{~L} \cdot \mathrm{mol}^{-1} \cdot \mathrm{cm}^{-1}\right)$, and 1 is the cuvette width $(1 \mathrm{~cm})$.

\subsection{Determination color intensity, violet index and browning index}

The color intensity (CI) measured to indicate the strength of the color of the extract. The measurement is examined by scanning the extract at the respective $\mathrm{pH}$ at the visible region ( $400 \mathrm{~nm}$ to $700 \mathrm{~nm}$ ) to determine the peak $(\lambda \max )$. The CI calculated by the following equation.

$$
C I=\left(A_{\max }-A_{700}\right) X D F[9]
$$

The violet index (VI) determined the strength of violet hue of the extract by dividing the absorbance at 580 $\mathrm{nm}$ to the absorbance at $520 \mathrm{~nm}$ [10]. 


$$
V I=\left(A_{580}-A_{700}\right) /\left(A_{520}-A_{700}\right)
$$

The browning index (BI) is measured to indicate the brown compound in the extract. The brown compound could be contributed either from the degradation of anthocyanins or the polymerization of anthocyanins. The BI calculated the following equation.

$$
B I=\left(A_{420}-A_{700}\right) /\left(A_{\lambda \max }-A_{700}\right) X D F[9]
$$

\subsection{Analysis of total phenolic content}

The total phenolic compound (PC) was determined as gallic acid equivalent (GAE) by the Folin-Ciocalteu modified method [11]. The gallic acid standard was made by diluting a $1000 \mathrm{ppm}$ gallic acid solution to 50 , $100,125,150$, and $200 \mathrm{mg} .1$ gallic acid and then the absorbance was measured at $765 \mathrm{~nm}$.

The analysis was done by placing $0.1 \mathrm{ml}$ of sample in a test tube, added with $0.4 \mathrm{ml}$ sodium carbonate, then mixed with a vortex. Then, $0.5 \mathrm{ml}$ of Folin-C reagent was added to the test tube and mixed with vortex again. The solution was incubated for 60 minutes at room temperature. After incubation, the solution is placed into a cuvette and the absorbance measured at $756 \mathrm{~nm}$.

The PC calculated by the following equation.

$$
\mathrm{PC}(\mathrm{mg} / \mathrm{L} \mathrm{GAE})=(\mathrm{A} \times \mathrm{DF}) / \mathrm{m} \text {. }
$$

A was the absorbance of the sample at $765 \mathrm{~nm}(\mathrm{~A})$, $\mathrm{DF}$ was a dilution factor, and $\mathrm{m}$ was the gradient of gallic acid standard curve $\left(\mathrm{A} / \mathrm{mg} . \mathrm{L}^{-1}\right.$.)

\subsection{Determination of degradation kinetics}

The kinetics of the degradation of CI and TMA described by the first-order reaction are as follows.

While the $\mathrm{k}$-values and half-life (t1/2) values for the first-order reactions were calculated with Eq. (7) and Eq. (8) respectively,

$$
\begin{aligned}
& \ln [A] \\
& =-k t+\ln [A] o . \\
\mathrm{t}_{0.5} & =\frac{\ln (2)}{k} \ldots \ldots \ldots . .
\end{aligned}
$$

$[\mathrm{A}]$ is the concentration or content at a certain time, $\mathrm{k}$ is the kinetic degradation constant (unit of time-1), $t$ is the time (unit of time), $[\mathrm{A}]_{0}$ is the concentration or content at initial time, and t 0.5 is the half-live (units of time).

\subsection{Statistical analysis}

Statistical analyses involved in this experiment was 2 ways Analysis of Variance (ANOVA). The data analyzed with the help of Design-Expert ${ }^{\circledR}$ version 7.0.0. (StatEase Inc.). The post-hoc analysis was Tukey HSD test that conducted using OpenStat ${ }^{\circledR}$.Statistical Analysis.

All data obtained from the experiments were processed and analyzed with ANOVA (Analysis of Variance) using DesignExpert and OpenStat for Tukey and Post-hoc test. The correlations and the.

\section{RESULTS AND DISCUSSION}

\subsection{Best time and temperature of the extraction}

Time and temperature are two parameters that are commonly studied to maximize the anthocyanin extracted from a source $[8,12]$. A research of the extraction of anthocyanin from Clitoria ternatea flower revealed that the optimum time and temperature of the extraction are 30 minutes and $60^{\circ} \mathrm{C}$, respectively [8]. The best time and temperature to extract anthocyanins from Bauhinia purpurea flowers are 30 minutes and $45^{\circ} \mathrm{C}$ [12]. Meanwhile, the temperature of $60^{\circ} \mathrm{C}$ is also stated by the other study as the excellent extraction temperature for anthocyanin from several sources, regardless of the extractant used [13].

A relatively similar result shown by this research. The highest TMA of $\mathrm{C}$. hirta obtained by the extraction at $45^{\circ} \mathrm{C}$ and $60^{\circ} \mathrm{C}$, while the highest PC yielded by the extraction at $60^{\circ} \mathrm{C}$ (Figure 2). In contrast, there was no significant effect given by the extraction time ( $p>0.05)$ to the TMA and PC. These results brought us to choose $60^{\circ} \mathrm{C}$ and 30 minutes as the selected temperature and time to extract the anthocyanin from $\mathrm{C}$. hirta. The average TMA and PC of $C$. hirta extracted at $60^{\circ} \mathrm{C}$ were $43.81 \pm$ $2.99 \mathrm{mg} / \mathrm{L}$ and $1314.43 \pm 119.97 \mathrm{mg} \mathrm{GAE} / \mathrm{L}$.
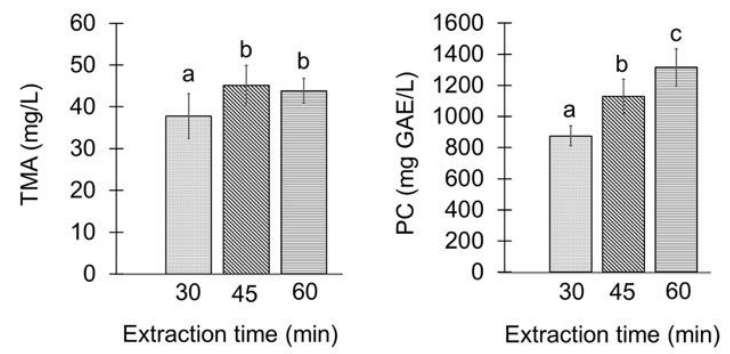

Figure 2 Total monomeric anthocyanin (TMA) (left) and total phenolic content (PC) (right) of Clidemia hirta extracted at $30,45,60^{\circ} \mathrm{C}$ (average of 3 level of time: 30, 60, 90 min \pm standard deviation). Averages with the same letter are not significantly different (Tukey HSD, p>0.05). 


\subsection{Anthocyanin quality and at various $\mathrm{pH}$}

Through the spectrogram, the color quality of an anthocyanin source extract at various $\mathrm{pH}$ can be evaluated. The common color quality parameters of an anthocyanin are $\lambda_{\max }, \mathrm{CI}, \mathrm{VI}$, and BI. Several characteristics are interesting to be highlighted from the spectrogram and color quality of $C$. hirta extract (Figure 3).

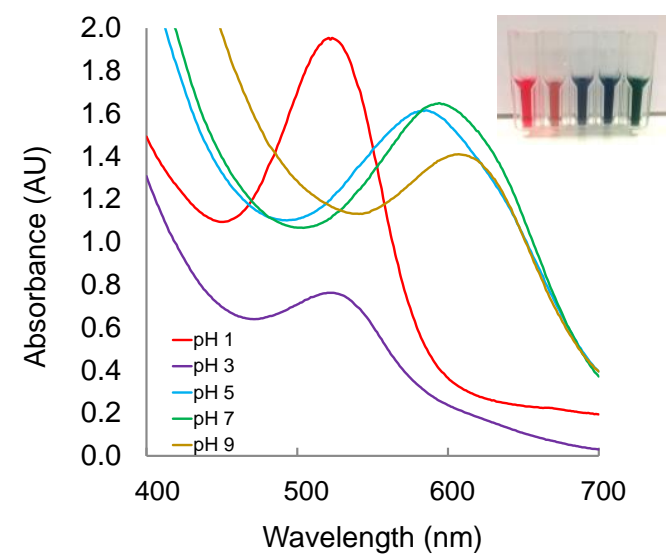

\begin{tabular}{ccccc}
\hline $\mathbf{p H}$ & $\boldsymbol{\lambda}_{\max }(\mathbf{n m})$ & $\mathbf{C I}$ & $\mathbf{V I}$ & $\mathbf{B I}$ \\
\hline 1 & 523 & 8.80 & 0.22 & 0.61 \\
3 & 522 & 3.66 & 0.42 & 1.31 \\
5 & 584 & 6.10 & 1.52 & 1.15 \\
7 & 594 & 6.35 & 1.69 & 1.26 \\
9 & 607 & 5.08 & 1.16 & 2.46 \\
\hline
\end{tabular}

Figure 3 Picture, light absorbances and color quality ( $\lambda$ max, color intensity - CI, violet index - VI, and browning index $-\mathrm{BI}$ ) of Clidemia hirta extract at $\mathrm{pH} 1$, $3,5,7$, and 9

First, $\lambda_{\max }$ and $\mathrm{CI}$ at $\mathrm{pH}$ 5. Most simple anthocyanins are colorless or express the lowest color intensity at $\mathrm{pH} 4$ to $5[2,12,14]$ due to the presence of colorless $\mathbf{B}$ as the predominant species. The C. hirta showed a deep blue color, which indicates that the deprotonation of red $\mathbf{A} \mathbf{H}^{+}$ to purple quinoidal base (A) (kinetic reaction) won the competition with the hydration of $\mathbf{A H}^{+}$to colorless $\mathbf{B}$ (thermodynamic reaction) [16]. Hence, based on the intensity of the color, $C$. hirta might be categorized as the potential source of blue colorant for food.

Second, however, the extract showed high adverse BI at $\mathrm{pH}>3$. All extracts at $\mathrm{pH}>3$ showed higher absorbance at $420 \mathrm{~nm}$ than at $\lambda_{\max }$. The high BI degrades the quality of red, purple, or blue color of an anthocyanin.

Third, the CI at $\mathrm{pH} 3$ was about $42 \%$ of the $\mathrm{CI}$ at $\mathrm{pH}$ 1. In other words, almost $60 \%$ of $\mathbf{A} \mathbf{H}^{+}$hydrated to $\mathbf{B}$. This percentage is lower than the percentage of Bauhinia purpurea extract (67\%), but higher than the percentage of Thunbergia erecta extract $(30 \%)$ at the same $\mathrm{pH}[13$, $15]$.

\subsection{Anthocyanin stability and at various $\mathrm{pH}$}

In general, anthocyanin stability decreases as the increase of the $\mathrm{pH}$. Table 1 shows that the $C$. hirta extract follows the common pattern. Both color and anthocyanin performed the highest stability at $\mathrm{pH} 1\left(\mathrm{t}_{0.5}=126.85\right.$ days) and the lowest stability at $\mathrm{pH} 9\left(\mathrm{t}_{0.5}=0.14\right.$ days $)$. C. hirta extract showed a relatively poor performance both as the colorant and source of monomeric anthocyanin at $\mathrm{pH} 5$ or higher.

Interesting characteristics shown by the extract at $\mathrm{pH}$ 1 and $\mathrm{pH}$ 3. The color stability of the extract was much higher than the monomeric anthocyanin stability.

At $\mathrm{pH} 3$, the $\mathrm{t}_{0.5}$ of the color was 21.19 days, while the $\mathrm{t}_{0.5}$ of monomeric anthocyanins was 5.73 . The much higher color stability indicated that some monomeric anthocyanin converted to polymeric anthocyanin through a condensation reaction that also occurred in wine during aging [17]. Polymeric anthocyanins are red and are not a $\mathrm{pH}$-dependent pigment [17].

The increase of polymeric anthocyanin in C. hirta extract at $\mathrm{pH} 1$ and 3 during storage was evident in this research (data is not provided). The relatively high color stability and the formation of polymeric anthocyanin during storage at a low $\mathrm{pH}$ promotes $C$. hirta as the red colorant for low $\mathrm{pH}$ food products such as high acidic fermented beverages.

Table 1 First order degradation kinetics and half-life (t.05) of color intensity and monomeric anthocyanin of C. hirta extract at various $\mathrm{pH}$

\begin{tabular}{rrrrrrr}
\hline \multirow{2}{*}{$\mathrm{pH}$} & \multicolumn{4}{c}{$\begin{array}{c}\text { Color } \\
\text { Intensity }\end{array}$} & \multicolumn{3}{c}{$\begin{array}{c}\text { Monomeric } \\
\text { Anthocyanin }\end{array}$} \\
\cline { 2 - 7 } & $\mathrm{R}^{2}$ & $\mathrm{k}, \mathrm{d}^{-1}$ & \multicolumn{1}{c}{$\mathrm{t}_{0.5}, \mathrm{~d}$} & $\mathrm{R}^{2}$ & ${\mathrm{k}, \mathrm{d}^{-1}}^{\mathrm{t}} \mathrm{t}_{0.5}, \mathrm{~d}$ \\
\hline 1 & 0.99 & 0.0055 & 126.85 & 0.92 & 0.0105 & 66.14 \\
3 & 0.89 & 0.0327 & 21.19 & 0.91 & 0.1211 & 5.73 \\
5 & 0.78 & 0.1647 & 4.21 & 0.94 & 0.2246 & 3.09 \\
7 & 0.80 & 0.7022 & 0.99 & 0.66 & 0.4038 & 1.72 \\
9 & 0.93 & 5.0242 & 0.14 & 0.98 & 7.3694 & 0.09 \\
\hline
\end{tabular}

\section{CONCLUSION}

The hot aqueous extraction $\left(60^{\circ}\right)$ at $\mathrm{pH} 1$ for 30 minutes could be considered to extract anthocyanin form harendong bulu or Clidemia hirta berry. The extraction at a longer time gave no significant effect to the anthocyanin yielded $(\mathrm{p}>0.05)$.

Anthocyanin in $C$. hirta extract showed a characteristic that was differ to most simple anthocyanins. It showed a deep blue color at $\mathrm{pH}$, but with a relatively high browning index. However, the extract showed low color stability at the $\mathrm{pH}\left(\mathrm{t}_{0.5}\right.$ was 
lower than five days). Several techniques, such as intermolecular copigmentation with phenolic compounds and matrix development with macromolecules, are suggested to increase the color stability.

The most promising result of the $C$. hirta extract as a potential food colorant is at $\mathrm{pH} 3$. At this $\mathrm{pH}, C$. hirta extract retained its $50 \%$ color for 21 days at room temperature. As a further evaluation, the study of the application of $C$. hirta extract in several high acidic beverages at various temperatures is recommended. In general, the color of an anthocyanin is much more stable at the lower temperature.

\section{REFERENCES}

[1] K. Yoshida, M. Mori and T. Kondo, Blue flower colour development by anthocyanins: from chemical structure to cell physiology., Natural Product Reports, vol. 26, 2009, 26, p. 884-915

[2] A. M. Marpaung, N. Andarwulan, P. Hariyadi and D. N. Faridah, Study on Spectral Characteristics of Selected Unacylated, Monoacylated and Polyacylated Anthocyanin Source Plant Extract at Various $\mathrm{pH}$, in 15th ASEAN Conference on Food Science and Technology, Ho Chi Minh City, 2017.

[3] A. M. Marpaung, Tinjauan manfaat bunga telang (Clitoria ternatea 1.) bagi kesehatan manusia, Journal of Functional Food and Nutraceutical, vol. 1, no. 2, 2020, pp. 1-23.

[4] S. J. DeWalt and J. S. I. K. Denslow, NaturalEnemy Release Facilitates Habitat Expansion of the Invasive Tropical Shrub Clidemia hirta, Ecology, vol. 85, no. 2, 2004, pp. 471-483.

[5] J. Lowry, " Anthocyanins of the Melastomataceae, Myrtaceae and some allied families," Phytochemistry, vol. 15, 1976, pp. 513-516.

[6] A. M. Marpaung, N. Andarwulan, P. Hariyadi and D. N. Faridah, "Spectral Characteristics and Color Stability of Melastomataceae and Clitoria ternatea L. Extracts," in 17th Food Innovation Asia Conference, Bangkok, 2015.

[7] A. M. Marpaung, I. Zhang and H. Sutanto, "Colour Behaviour and Stability of Anthocyanin in the Blue Flower of Stachytarpheta jamaicensis and Hydrangea macrophylla," IOP Conference Series: Materials Science and Engineering, vol. 532, 2019, pp. 1-7.

[8] A. M. Marpaung, N. Andarwulan and E. Prangdimurti, The optimization of anthocyanin pigment extraction from butterfly pea (Clitoria ternatea L.) petal using Response Surface Methodology, Acta Horticulturae, vol. 1011,2013, pp. 205-211.

[9] A. M. Marpaung, N. Andarwulan, P. Hariyadi and D. N. Faridah, The Difference in Colour Shifting of Clitoria ternatea L. Flower Extract at $\mathrm{pH} 1,4$, and 7 during storage, Current Nutrition and Food Science, vol. 15, no. 7, 2019, pp. 694-699.

[10] M. Cisse, F. Vaillant, A. Kane, O. Ndiayea and M. Dornier, Impact of the extraction procedure on the kinetics of anthocyanin and colour degradation of roselle extracts during storage, Journal of the Science of Food Agriculture, vol. 92, 2012, p. 1214-1221.

[11] A. Waterhouse, Determination of Total Phenolics, in Current Protocols in Food Analytical Chemistry, New York, John Wiley \& Sons, 2001, pp. I1.1.1-I1.1.8.

[12] C. C. Chang, M. H. Yang, H. M. Wen and J. C. Chern, Estimation of Total Flavonoid Content in Propolis by Two Complementary Colorimetric Methods, Journal of Food and Drug Analysis, vol. 10, no. 3,2002, pp. 178-182.

[13] A. M. Marpaung, D. P. Djani and D. Rahmawati, Anthocyanin from Bauhinia purpurea flower: Extraction, color characteristics and stability, Indonesian Food and Nutrition Progress, vol. 17, no. 1, 2020, pp. 1-5.

[14] T. M. Rababah, F. Banat, A. Rababah, K. Ereifej and W. Yang, Optimization of extraction conditions of total phenolics, antioxidant activities, and anthocyanin of oregano, thyme, terebinth, and pomegranate, Journal of Food Science, vol. 75, no. 7,2010, pp. 626-632.

[15] A. M. Marpaung and R. P. Ramdhani, Color Characteristics and Stability of Anthocyanin in Fresh Thunbergia erecta Flower Extract, Indonesian Journal of Natural Pigments, vol. 2, no. 2, 2020, pp. 31-35.

[16] P. Trouillas, J. C. Sancho-García, V. De Freitas, J. Gierschner, M. Otyepka and O. Dangles, Stabilizing and modulating color by copigmentation: insights from theory and experiment, Chemical Review, vol. 116, 2016, p. 4937-4982.

[17] F. He, N.-N. Liang, L. Mu, Q.-H. Pan, J. Wang, M. J. Reeves and C.-Q. Duan, Evolution, Anthocyanins and Their Variation in Red Wines II. Anthocyanin Derived Pigments and Their Color, Molecules, vol. 17, 2012,pp. 1483-1519. 